\title{
JUVENILE EASTERN SCREECH-OWL DIES EATING A RED-BREASTED NUTHATCH
}

JAMES R. DUNCAN AND ROBERT W. NERO, Wildlife Branch, Manitoba Natural Resources, Box 24, 200 Saulteaux Crescent, Winnipeg, MB R3J 3W3. E-mail: jduncan@nr.gov.mb.ca

A high percentage of young birds do not survive their first year of life. Documented first-year mortality rates for juvenile Eastern Screech-owls, for example, range from $64 \%$ to $70 \%$; the causes of death in order of decreasing frequency include vehicle collision, shooting, drowning, dog or cat kill, window or wall strikes, trapping, and poisoning. ${ }^{3}$ Some forms of mortality, e.g., road kills, are more readily observable, compared to natural causes of death. This paper describes a case in which a nearly full-grown juvenile Eastern Screech-owl, found dead near a nest site in a residential area of Winnipeg, apparently died accidentally as a result of attempting to swallow an entire Red-breasted Nuthatch.

Manitoba Natural Resource Officer Denis Ayotte, responding to a call early in the morning of 17 May 1998 about an owl attacking people in a residential area in north Winnipeg, arrived on the scene at 5:15 a.m. This was on McKenzie Street adjacent to Strathcona Elementary School. There Ayotte was met by Winnipeg police officer Don MacLennan, who had received reports of an owl diving at people. While they were talking, the owl dove down and struck Don hard on the back of his bare head. He was not impressed! According to a $\mathrm{CBC}$ radio broadcast on 25 May 1998, Robert Keillar, a newspaper delivery man making his early morning rounds on the same street, had been hit by an owl (presumably the same female

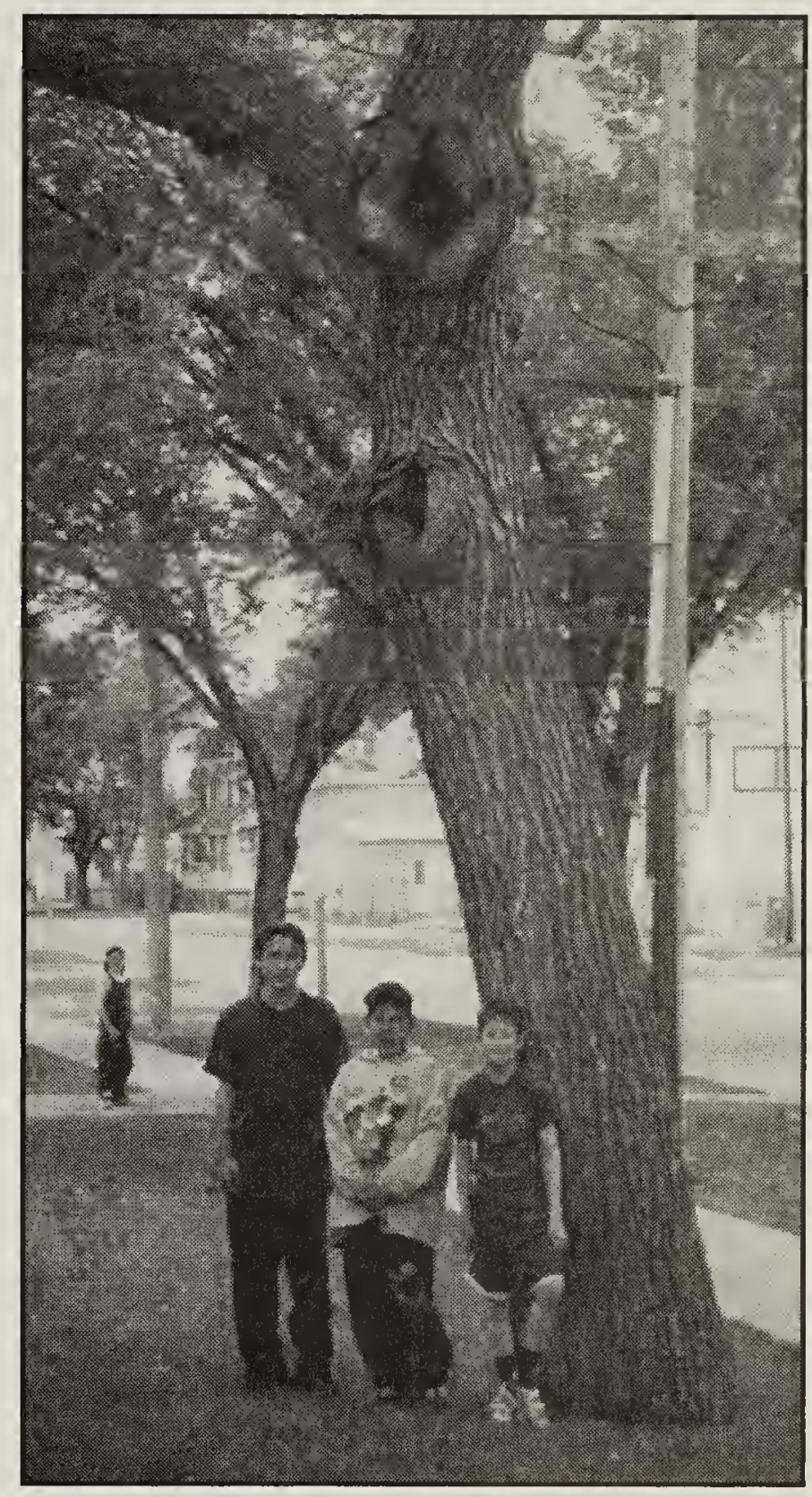

Screech-owl nest cavity with students of Strathcona Elementary School, Winnipeg.

- Duncan and Nero

parent) on the back of the head on four different days, the last time sending him to hospital. When asked why he did not start wearing a hard hat to protect himself, Robert replied that he didn't want the owl to get hurt hitting the hat! 
On 11 May, Winnipeg Animal Services staff received a call about owls attacking people at this same location. They contacted Tracy Maconachie, whom they knew in connection with Peregrine Falcon monitoring, and she rode with them to identify the problem birds. Upon their arrival at 8:45 p.m., four owls were found perched in a tree across the street from the school. The school caretaker, who told them that children had been throwing stones at the owls, indicated that the nest site was in the elm tree beside the school. Apparently, owls had used this site in previous years. Natural Resources biologist Ron Larche confirmed that he had visited the same area in spring 1996 in response to reports of aggressive owls, which he identified as adult Eastern Screech-owls defending recently fledged young.

\section{N.R.O. Ayotte and the officer} observed a quiet family group of owls perched high in a Manitoba maple, and found a dead juvenile owl lying nearby on the street. They were puzzled to see that the dead owl had a dead Redbreasted Nuthatch in its mouth. Ayotte cautioned some young boys about using care in the vicinity of the owls, and mentioned that they were protected birds, then he drove to Nero's house to verify the identity of the owl and to turn it over for study. Ayotte then returned to the site with Nero, arriving in midmorning. Four juvenile owls and an adult were found still perched closely together in the same tree. A small pellet found by Nero beneath this tree consisted of feathers and a few small bird bone fragments. While they were examining the pellet, two large cocker spaniels ran up and down the street. Three young boys playing on the sidewalk a short distance away, when questioned, identified a large natural cavity opening about $2.5 \mathrm{~m}$ high on the north side of an old American elm immediately adjacent to their school as the owl nest site. This was just across the street from the tree with the family group of owls. All six owls observed were of the grey colour phase. In a study of Screech-owls at Dauphin, Manitoba, it was noted that a male owl used a cavity in a mature elm as a daytime roost, the nest site being a cavity in a maple $30 \mathrm{~m}$ away. ${ }^{6}$

It appeared as if the dead owl had choked and died while attempting to swallow the nuthatch, which was an adult male. Accordingly, we went to some effort to see if this could be shown to be the case. We had the owl $x$-rayed and the next day the thawed carcass was measured, weighed, and then dissected. We found that the $12 \mathrm{~mm}$ long bill of the nuthatch, relatively long for a bird of its size, and sharply pointed, had penetrated $8 \mathrm{~mm}$ into the soft tissue at the right back corner of the palate (roof of the mouth), and into the narrow space between the eyeball and the skull. The back of the nuthatch's head was also lodged between the owl's lower jaw bones in such a way that it could not be swallowed or ejected. Indeed, the owl's lower jaw had to be cut on either side to dislodge the nuthatch's head during the dissection. The only other injury we observed was a punctured abdominal cavity near the owl's lower back, possibly the result of the owl being picked up by a dog.

The owl weighed 160 grams, as much as an adult male. ${ }^{3}$ The presence of testes confirmed that it was a male. The flight feathers of the wing and tail were still growing but the following measurements were recorded: wing chord was $142 \mathrm{~mm}$ and tail length was $61 \mathrm{~mm}$. These are below average, but within the range of values for adult Screech-owls measured elsewhere in North America. ${ }^{3}$

The diet of the Eastern Screech-owl, 


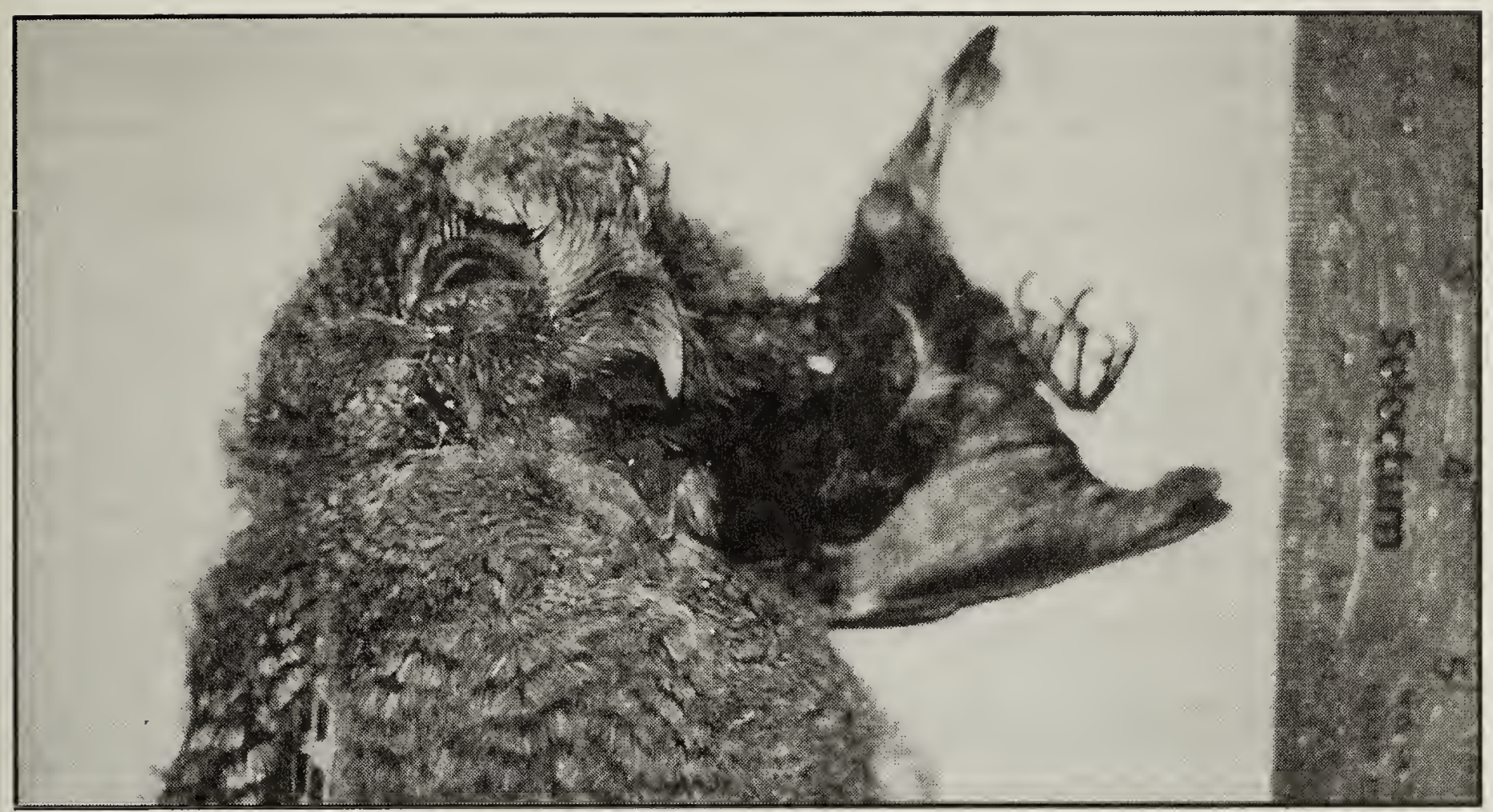

Young Eastern Screech-owl with Red-breasted Nuthatch stuck in its mouth.

- Duncan and Nero

the most varied of any North American owl, includes terrestrial and aquatic invertebrates and vertebrates - a 4-kg domestic chicken is the largest prey known to be killed! ${ }^{3}$ Birds are taken as prey more frequently in cities, especially during migration..$^{3,4}$ Ground-feeding birds are taken more frequently than foliage feeders, and male birds more often than females, both bird and mammal prey typically being killed or disabled by biting and tugging on the head and neck; often they are partly plucked before being consumed. ${ }^{3}$ The nuthatch had some feathers missing from its head, neck and breast and its neck was broken; it seems likely that it was dead when the young owl received and attempted to swallow it. The Redbreasted Nuthatch is uncommon in Winnipeg except during migration, spring migration being in late April and May. ${ }^{1}$

Two aspects of Eastern Screech-owl behaviour likely resulted in the death of this owl. Screech-owls typically consume bird and mammal prey head first, and hungry owlets can be very aggressive towards each other; up to $64 \%$ of cases of brood mortality are due to siblicide (cannibalism). ${ }^{3}$ After young leave the nest cavity they can still aggressively compete for food when parents return from a hunting foray with prey. When a young owl receives prey from an adult, it quickly swallows it. Perhaps the owlet we examined did likewise, and in its haste to swallow the nuthatch it inadvertently punctured its mouth with the bill of its intended meal.

It is not certain that the owlet died directly as a result of the puncture. We surmise that the owlet panicked due to this painful injury and its inability to remove the nuthatch, then perhaps fell to the ground and continued its struggle which might have attracted the attention of a dog. The owlet may then have been bitten and carried a short distance before its parent would have attacked the predator in defense of its young. This also could have increased the parent's aggressive behaviour to people at this site. Adult owls have been known to attack the head and upper body region of humans, and have attacked cats, raccoons, and even eastern cottontails that have come within a few meters of an owl nest or roost tree with young owls. ${ }^{2}$ 
Regardless of the exact timing and sequence of these events, we conclude that this young owl could not have extracted the nuthatch's head from its mouth. Thus, this paper documents an unusual accidental cause of death for a juvenile Eastern Screech-owl resulting from the consumption of avian prey. Screech-owls in Winnipeg seem to lead precarious lives. An earlier report in the Blue Jay describes one that apparently died when bitten by a shrew, its intended prey. $^{5}$

\section{Acknowledgements}

Rob Mazur and Sonia Langlais of the South Interlake Animal Hospital, Stonewall, kindly took $\mathrm{x}$-rays at cost to assist with this investigation. Denis Ayotte reviewed earlier versions of the manuscript.

\section{Literature Cited}

1.CLEVELAND, N.J. et al. 1988. Birder's guide to southeastern Manitoba. Eco Series No. 1. Manitoba Naturalists Society, Winnipeg, MB. 91 pp.
2.GEHLBACH, F.R. 1994. The Eastern Screech Owl: life history, ecology, and behavior in suburbia and the countryside. Texas A\&M Univ. Press, College Station, TX. 302 pp.

3.GEHLBACH, F.R. 1995. Eastern Screech-owl (Otus asio). In The Birds of North America, No. 165 (A. Poole and F. Gill, eds.). The Academy of Natural Sciences; Philadelphia, and The American Ornithologists' Union; Washington, D.C. 24 pp.

4.MAZUR, K.M. 1992. Fall food of the Eastern Screech-owl in Manitoba. Blue Jay 50:33-35.

5.NERO, R.W. 1994. Short-tailed shrew apparent cause of mortality of Eastern Screech-owl. Blue Jay 52:176-178.

6.WALLEY, W.J., and C.F. CLYDE. 1996. Occurrence and breeding of the Eastern Screech-owl north of the Riding Mountains, Manitoba. Blue Jay 54:89100.

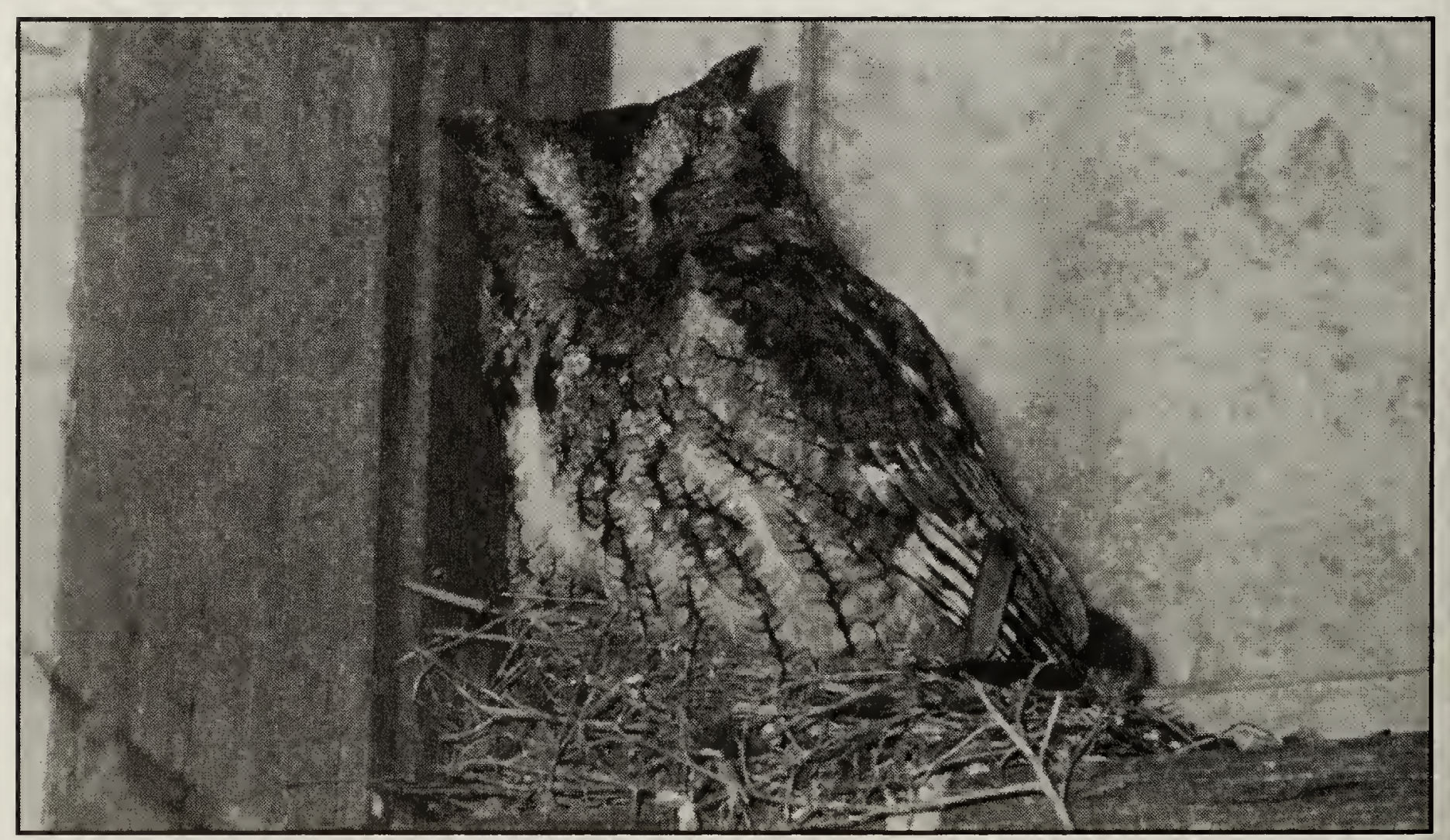

